\title{
Shifting frames for local people and forests in a global heritage: the Thung Yai Naresuan Wildlife Sanctuary in the context of Thailand's globalization and modernization
}

\author{
Reiner Buergin \\ Working Group Socio-Economics of Forest Use in the Tropics, University of Freiburg, Freiburg, Germany
}

Received 19 June 2001; received in revised form 5 April 2002

\begin{abstract}
Focusing on the case of the World Heritage Site and Wildlife Sanctuary Thung Yai Naresuan, the paper sketches the interdependences of international and national forest and conservation policies in Thailand since the middle of the 19th century. In the context of Thailand's globalization and modernization, these policies resulted in a coercing conservationism which focuses increasingly on the so-called 'hill tribe' ethnic minority groups. The shifting cultural and political framings of the area that became a national wildlife sanctuary and a 'global heritage' reflect external economic, political, and ideological interests. The people of the Karen ethnic minority group who live in the sanctuary are conceived of as a disruptive factor and never have had a chance to participate in these framings. After the designation of the area as a World Heritage Site, the remaining villages face increasing pressure from the Royal Forest Department which is trying to remove them with the help of the Military. Drawing on the different vested interests and the relativity of cultural conceptualizations, the paper questions the external framing, pointing to three major problems that are raised with regard to Thung Yai, but are symptomatic of modern conservationism at large: inconsistencies between normative claims and political practice; distortions of scale between conceptions designed at different levels of social space from the local to the global, and; the problem to reconcile conflicting cultural patterns and conceptualizations. The paper argues for a reframing of the conflict to conceive the Karen in Thung Yai as an integral part of the 'global heritage'.
\end{abstract}

(C) 2003 Elsevier Ltd. All rights reserved.

Keywords: Conservationism; Modernization; Globalization; Ethnicism; Protected areas; Forest policies; Local resistance; Thailand; Karen

\section{Conservationism and modernization: contesting com- plements}

In December 1991, the two wildlife sanctuaries Thung Yai Naresuan and Huai Kha Khaeng in Western Thailand were declared a heritage of humankind by the UNESCO World Heritage Committee due to their outstanding universal value for global biodiversity. Together they encompass more than $6200 \mathrm{~km}^{2}$ and are the core area of the so-called Western Forest Complex, constituting Thailand's largest remaining forest area with about 18,700 $\mathrm{km}^{2}$ (see Fig. 1). For conservationists the designation of Thailand's first and only Natural World Heritage Site was a great success in their long lasting efforts to protect the vast forest area against

E-mail address: reiner.buergin@mail.uni-freiburg.de (R. Buergin). detrimental effects of national modernization and development. People of the Karen ethnic minority group, who live in the area for at least 200 years, were also among the threats mentioned in the nomination submitted by Thailand's Royal Forest Department (Seub and Stewart-Cox, 1990). From a conservationist perspective their existence in the sanctuary is an unfortunate flaw, requiring at least careful monitoring and management if resettlement is unfeasible. Stereotyped as 'hill tribes', the Karen are at the edge if not outside of Thai society. State authorities started to evict them in successive waves since the wildlife sanctuaries were demarcated in the 1970s. Ten years after the declaration as a World Heritage Site, the Forest Department and the Military finally seem determined to remove the remaining villages. As the legal ground for their eviction is still rather shaky, the state authorities use strategies of exclusion and ethnicism together with restrictions and terror to convince the Karen to resettle 'voluntarily'. 


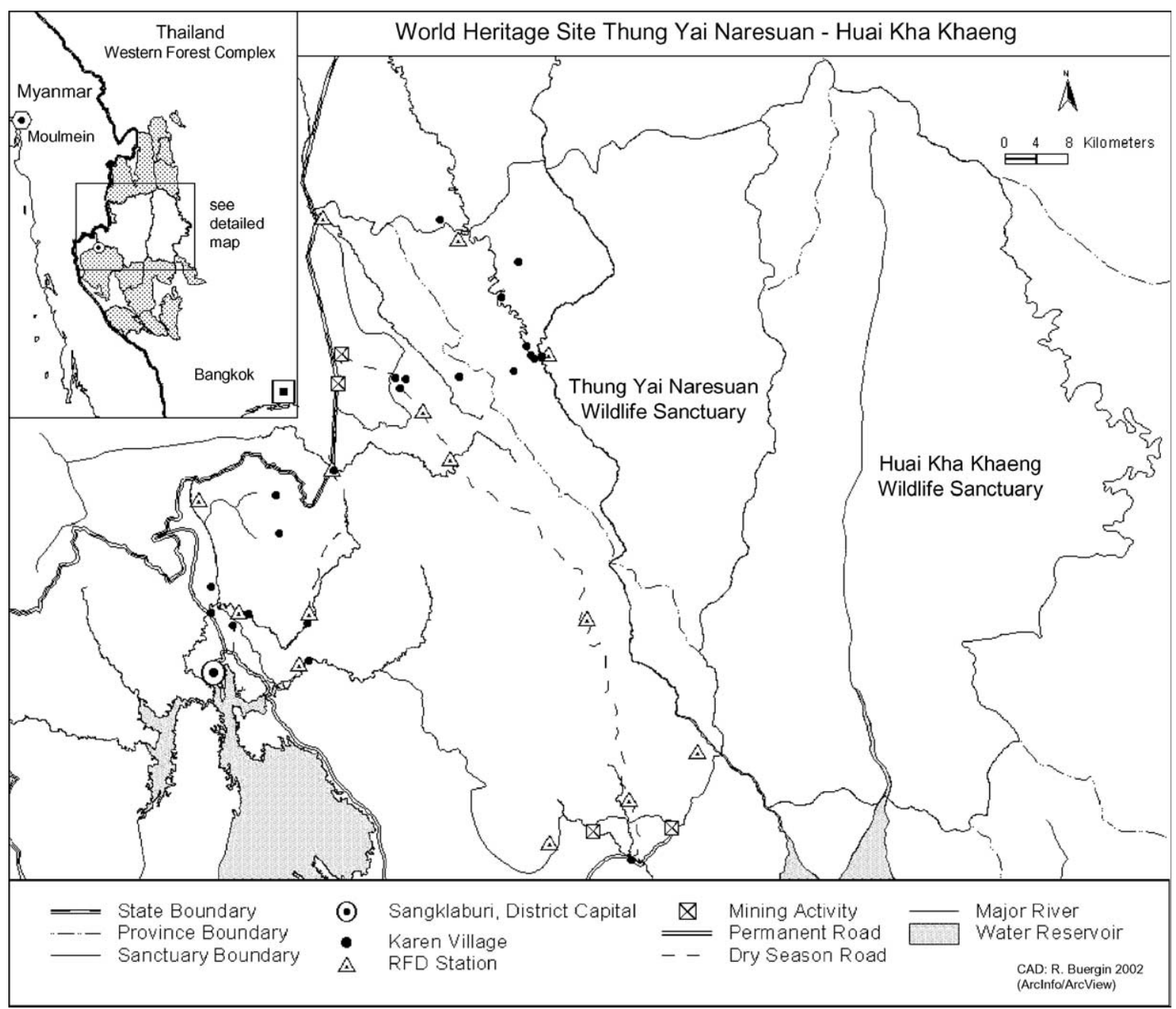

Fig. 1. World Heritage Site Thung Yai Naresuan-Huai Kha Khaeng, Western Thailand.

From a generalizing and 'distant' perspective Thung Yai is another example for widespread conflicts between actors at different levels of social space from the 'local' to the 'global' due to competing interests in forests and nature conservation. Modern conservationism emerged in the 19th century and, from the beginning, showed a distinctive ambivalence: on the one hand nature conservation is conceived as a means to incorporate 'nature' or 'wilderness' - primarily defined as 'the other' to the space of human creation and dominance - into the sphere of human control; on the other hand it aims at the preservation of the 'otherness', the protection of the autonomy of 'the wild'. This ambivalence reflects traits that are fundamental to the culture of modernity. Based on a marked distinction between 'humans' and 'nature', the history of 'modernity' can be conceived as a process in which the sphere of human control and creation is expanded on behalf of 'the other' in its different forms (e.g. Merchant, 1983; Nash, 1982). With growing awareness for a 'global environmental crisis', modern conservationism became a strong force supposed to regulate the relation between humankind and 'nature' that had become problematic in the process of global modernization ${ }^{1}$ (e.g. McNeely and Miller, 1984; Western and Pearl, 1989). Growing awareness for a global environmental crisis was accompanied by a crisis of modern identity in which the modernization paradigm became questionable too. Since the 1990s, the modernization discourse is widely superseded by a globalization discourse which relates the global environmental crisis and nature conservation to shifting power relations between

\footnotetext{
${ }^{1}$ The term 'global modernization' refers to the global spread of 'occidental' or 'modern' culture which extended its hegemony almost globally during the 19th and early 20th century. 'Modernization paradigm' denotes the global development conception of this culture of modernity that predominated after World War II. Globalization in this paper does not refer to a specific historic period, but generally to processes of growing global interdependence-including economic, social, political, and cultural processes - and may be conceived as part of an even broader historical development towards increasing social complexity.
} 
local, national, and global levels of social organization (e.g. Lipschutz and Conca, 1993; Goldman, 1998).

In the context of the modernization paradigm and the global environmental crisis, local conflicts over forests and conservation areas were predominantly framed as conflicts between 'global needs' for nature conservation and 'local needs' frequently leading to deforestation due to local 'poverty' and poor resource management. In this frame, 'development' and modern resource management is the appropriate way to solve the problem (e.g. World Bank, 1998). In scientific discourse this framing has been questioned on various grounds, pointing to non-modern local ecological knowledge and sustainable forest and land use systems (e.g. Williams and Baines, 1993; Warren et al., 1995), emphasizing national and international interests in the process of global modernization leading to deforestation (e.g. Peluso, 1992; Bryant, 1997), or referring to the cultural roots of modern concepts of nature and conservationism (e.g. Cronon, 1996; Braun and Castree, 1998). Within the international conservation discourse, by now, it is widely recognized that effective management of protected areas requires participation and specifically cooperation of the concerned local population (e.g. Wells and Brandon, 1992; Western and Wright, 1994). In national and international conservation politics the modernization paradigm still goes largely unchallenged. Here 'participation' often means communication about objectives and rules determined from 'outside' and 'above', and 'cooperation' predominantly is a question of appropriate incentives and sanctions. Positions relating nature conservation to local self-determination and cultural diversity rather draw on critical approaches to modernization and conceive the empowerment of local communities and the protection of cultural diversity as an alternative way to nature conservation (e.g. Howitt et al., 1996; Stevens, 1997).

This paper does not take a generalizing view in first line, but is primarily concerned with the specific case of Thung Yai. Contextualizing the present situation in time and social space, it argues for a revision of the external framing of the 'problem' Karen in Thung Yai. The paper is organized along two lines of orientation: on the one hand it is narrated along a temporal sequence from past to present, on the other hand along an axis of social space from 'global' to 'local'. Knowledge about the local situation mainly stems from anthropological field research in 1996/97, concentrating on the forest and land use as well as the political conflict about the villages in the sanctuary (Buergin, 2002b). The paper first sketches the historical and political context of the present conflict before turning to the history of the sanctuary and the local situation of the Karen in Thung Yai. External interests in the forests of the area, the emergence of international conservationism, and national controversies about nature conservation and modernization predominantly have determined the status of the area and the people. Since the late 1980 s, forest conservation in Thailand focuses increasingly on the removal of socalled 'hill tribes' from 'protected areas', based on a culturally defined nationalism and ethnicism. To support their interests, the ethnic minority groups have to refer to dominant discourses of modernity and conservation. They have little chance to shape positions of their own in these discourses. Presently, for the Karen in Thung Yai advocacy by national and international actors is the only possibility to draw attention to their situation.

This situation is problematic in various respects. First of all, the exclusion of the Karen from the discourses and decisions regarding their living place, as well as recent acts of terror of state agencies in the sanctuary, contradict democratic principles and human rights and the respective national and international commitments. On a more abstract level, the paper points to the problem of discursive hegemony, in particular with regard to the generalizing frames of thought and perception that were designed in rather encompassing social contexts like states or the 'international community' and are now used to define highly specific local situations. To some degree these frames necessarily distort perceptions of local situations. To adapt the generalizing frames to specific situations requires the participation and empowerment of local communities. Furthermore, the paper contrasts the modern concept of nature conservation with local conceptualizations of 'living space', and questions claims of modern concepts for universality and hegemony.

\section{Foreign interests in national forests and globalizing Thailand}

In the middle of the 19th century Great Britain could secure trade rights with Siam which marked an important turning point in Thailand's economic globalization (Sompop, 1989; Feeny, 1982). Western concepts of territoriality, nation state, rationality, civility, and modernity were crucial in the process of the emergence of the Siamese nation state toward the end of the 19th century (Thongchai, 1994, 2000b). The forests of Thailand, as valuable natural resources, did play an important role in these processes of globalization. Timber, and specifically Teak, was among the resources that became of major interest to the colonial powers and the regional elites (Renard, 1987; De'Ath, 1992).

The emerging nation state claimed very early control over these resources by establishing the Royal Forest Department (RFD) in 1896 under supervision of the British forester H.A. Slade. (For the history of the RFD and forest policies see Kamon and Thomas (1990), Sathi (1993), and Vandergeest (1996a), regarding the role of scientific forestry see Lang and Pye (2001).) The RFD 
was shaped according to the Indian and Burmese forest administration where most of the Thai foresters were educated. It was made responsible for all areas neither cultivated nor claimed by any other person or state authority. At the beginning of the 20th century, about $75 \%$ of the total land area fell into this category (Vandergeest, 1996a, 161f), and at the beginning of the 21st century the RFD still claims authority over almost half of the land area. During the first half of the 20th century, the main concern of the RFD was to allocate and control concessions for Teak extraction, predominantly executed by British companies. Besides, taxes on commercially used forest products were levied. Territorial control of the vast areas under the administration of the RFD was neither of interest nor feasible. Contrary to British forest management in India and Burma, constantly struggling to protect 'their' forests against 'encroachment' and 'unreasonable' forest use by local people (Bryant, 1994), there were only few restrictions on local forest use in Thailand until the middle of the 20 th century. Forest clearance for agricultural purposes was even encouraged by the state until the enactment of the Land Code in 1954. It was not before the 1950s and 1960s that a remarkable shift in forest policies took place, now increasingly trying to restrict local forest use and to improve territorial control through the demarcation of forest reserves. The reasons for this shift of policies are to be found in the growing importance of forests for 'national development' and conservationism. Both factors, to a high degree, were determined by international developments and interests.

In the wake of World War II, most of the colonial powers had lost their colonies. Among the scientific and political international 'forestry community' it was generally believed that Europe as well as the United States would be increasingly dependent on the timber resources of the tropical forests in future. At the World Forestry Congress in Helsinki in 1949, tropical forests for the first time received broad attention, and at the World Forestry Congress in Dehra Dun in 1954, the controversies regarding management and threats to tropical forests were of central interest. It was here that the Food and Agricultural Organization (FAO) of the UN, in a paper setting out basic principles, emphasized the importance of the tropical forests for the development of the developing countries as well as the detrimental effects of shifting cultivation for tropical forest resources. Conceptions of tropical forests as important resources for the process of modernization were to guide the forest policies of the FAO and many developing countries during the 1960s and beyond (Steinlin and Pretzsch, 1984).

This ideology of commercialization of tropical forests and condemnation of shifting cultivation for the sake of national and 'global' development is concisely expressed by an official of the FAO in 1957, in an appeal to gov- ernments, research centres, and other concerned institutions to combat shifting cultivation globally:

... shifting cultivation, in the humid tropical countries, is the greatest obstacle not only to the immediate increase of agricultural production, but also to the conservation of the production potential for the future, in the form of soils and forests.... The average density of only 14 men pr square mile (6 pr square $\mathrm{km}$ ) is so low that a world in expansion cannot tolerate this relative vacuum. This does not mean that the vacuum should be filled in by migrations, but every country must be made capable of contributing its share of agricultural produce for the benefit of all. (FAO Staff, 1957, p. 9)

The shifts of forest policies in Thailand, to a considerable degree, were in reaction to these international forest policies. In 1947 the RFD established the Forest Industry Organization (FIO) to improve wood production, and in 1951 the state-owned Thai Plywood Company was founded for wood extraction and processing. From the 1960s to the 1980 s, most of the time, almost $40 \%$ of the total land area were assigned as concession areas, and commercial forestry was of major concern for the RFD. The new objectives and conceptions of forestry also influenced perceptions and politics of the state authorities towards the ethnic minority groups categorized as 'hill tribes'. Most of them were living in the forested mountain areas, practising various forms of swidden cultivation. In 1964 swidden cultivation was prohibited which put the so-called 'hill tribes' into a state of permanent illegality and insecurity. However, it was not before the late 1990s that state authorities seriously tried to enforce the law.

\section{Development, deforestation and conservationism}

The global spread of modernization ideology and the expanding world market after World War II not only influenced national forest policies, but national development policy altogether, leading to rapid economic growth in Thailand during the second half of the 20th century. During the 1960s and 1970s, the driving force of this growth was the diversification and extension of cash cropping for the world market propagated by the state. ${ }^{2}$ Commercial interests in the resources of the forested areas of the country, concerns about national

\footnotetext{
${ }^{2}$ For a complex account of this economic development at the expense of the forests see Pasuk and Baker (1997, pp. 1-88), with a closer focus on deforestation see for example Feeny (1988), Hirsch (1987, 1990), and Lohmann (1993).
} 
security, a national development policy based on the extension of agricultural areas together with population growth resulted in the 'colonization' of the peripheral areas and rapid deforestation. In this process, many farmers settled in areas that had formerly been forest areas and were demarcated as forest reserves. While the Forest Department conceived of these settlers primarily as illegal encroachers-in conflict with the RFD's interests in commercial forest use and nature conservation, other state agencies, like the Ministry of Interior, the Agricultural Ministry, ${ }^{3}$ or the Military, were more concerned to legalize the villages in forest reserves and improve their economic conditions. But, the various efforts since the 1970s to legalize settlement and land use rights of these farmers have so far not been very successful.

In the early 1950 s, almost two thirds of the country were still covered with forest. In the early 1980s, the forest cover was officially estimated at less than one third of the total land area and deforestation was perceived as a problem by a broader public for the first time. The new public interest in forests and deforestation was due to increasing societal conflicts in Thailand in the context of the "closure of the frontier" 4 and contested resources in rural areas, but was also related to the growing international and national awareness of a 'global environmental crisis' and the accompanying upswing of international conservationism.

Modern concepts of nature conservation, together with modernization ideology, had gained a foothold in Thailand around the middle of the 20th century, and were linked to efforts to shape and delimit a national identity. Dr. Boonsong Lekagul, the 'father' of nature conservation in Thailand, had been a passionate hunter before he became the most prominent advocate for wildlife conservation after World War II (Vandergeest, 1996b, p. 260). His concerns met the interests of Field Marshal Sarit Thanarat who had taken power after a military coup in October 1958. Sarit perceived Thailand's 'nature'-its forests, wildlife, and natural monuments, as another important element of national identity besides the institution of Monarchy, Buddhism, and the Thai language. Thus, for him the conservation of 'nature' became a matter of national interest, and the 'destruction' of this nature, for example due to the

\footnotetext{
${ }^{3}$ The RFD is part of the Ministry of Agriculture, but maintains a rather independent and strong position within the Ministry. Regarding the settlements in forest reserves, there are considerable tensions between the RFD and other departments of the Ministry like for example the Agricultural Land Reform Office (ALRO).

${ }^{4}$ The expression (from Pasuk and Baker, 1997, p. 80) does not primarily denote a geographically definable phase of physical colonization, but rather the societal perception that there is no more 'wilderness' suitable for 'colonization'.
}

swiddening practices of non-Tai ${ }^{5}$ ethnic minority groups, were an assault on the nation. Under his military rule the legal basis for the establishment of protected areas was laid.

In Thailand, National Parks and Wildlife Sanctuaries were thus the outcome of a convergence between nationalist and conservationist understanding of nature as sacred. These two approaches were subsequently codified into two separate but similar laws: the 1960 Wildlife Conservation and Protection Act and the 1961 National Park Act... The legislation, and the guidelines for implementing the legislation, were based on the 1933 London Convention..., which set standard definitions for National Parks and 'strict natural reserves'. They incorporated the assumption that livelihood activities and nature are incompatible, an assumption which dominated the conservation community during the 1960s. Thus the law on Wildlife Sanctuaries in Thailand prohibits entry and all activities not explicitly sanctioned by Sanctuary officials. The law on National Parks does not explicitly prohibit entry but prohibits almost all activities construed as damaging vegetation or animal life. (Vandergeest, 1996b, 260f)

During the 1960s and 1970s, the demarcation of protected areas proceeded slowly. While, in the late 1970s, forest reserves altogether encompassed more than a third of the country, and concession areas for commercial forest use made up for almost $40 \%$ of the land area, protected areas accounted only for about $5 \%$. Within the same period, the forest cover had decreased rapidly and, in the early 1980 s, the areas declared forest reserves were considerably larger than the areas actually covered with forest (see Fig. 2). In the early 1980s, the RFD had to explain the rapid and ongoing deforestation of the country, which was pointing to the RFD's own failure, towards a conservation sensitive urban public, who was achieving increasing political power. At the same time, the RFD had to deal with some 10 million rural people, or about one fifth of the total population, who were living 'illegally' in areas that had been declared forest reserves or even protected areas. In the early 1990s almost one half of these 'forest areas' were used for agricultural purposes, constituting about one third of Thailand's whole agricultural area (see Fig. 3).

The Forest Department reacted with a new forest policy which Vandergeest terms "functional territorialization" (1996a, 168ff). While the failed 'demarcation policy' had been based primarily on the model of

\footnotetext{
${ }^{5}$ The term 'Tai' refers to linguistic/ethnic categories, while 'Thai' indicates aspects of formal nationality.
} 
Deforestation, Forest Reserves, Concession and Protected Areas

in Thailand 1950-1998 (in \% of total land area, $513.115 \mathrm{~km}^{2}$ )

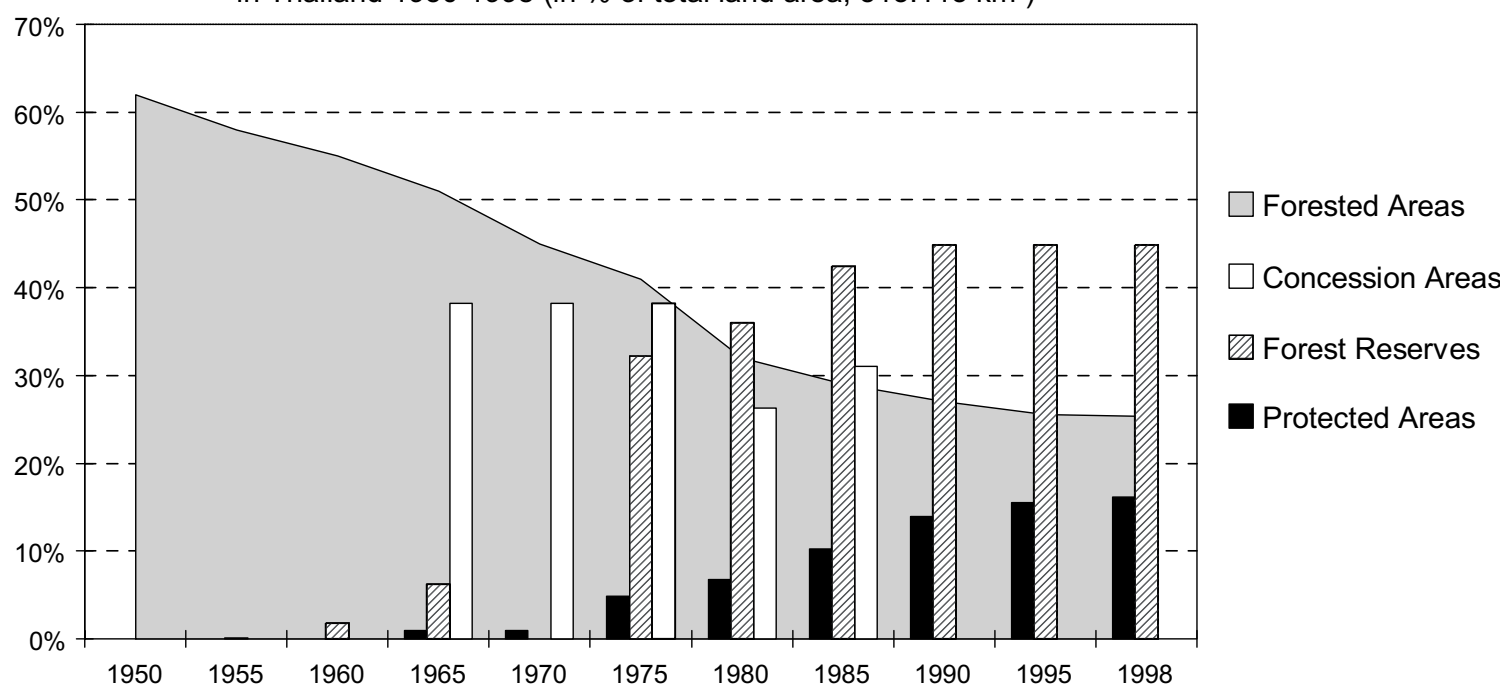

Fig. 2. Deforestation, forest reserves, concession and protected areas. Sources: RFD (1985, 1993, 1995, 1999), Kamon and Thomas (1990), Vandergeest (1996a) and Pasuk and Baker (1997).

\section{Agricultural and Forest Areas in Thailand in 1993}

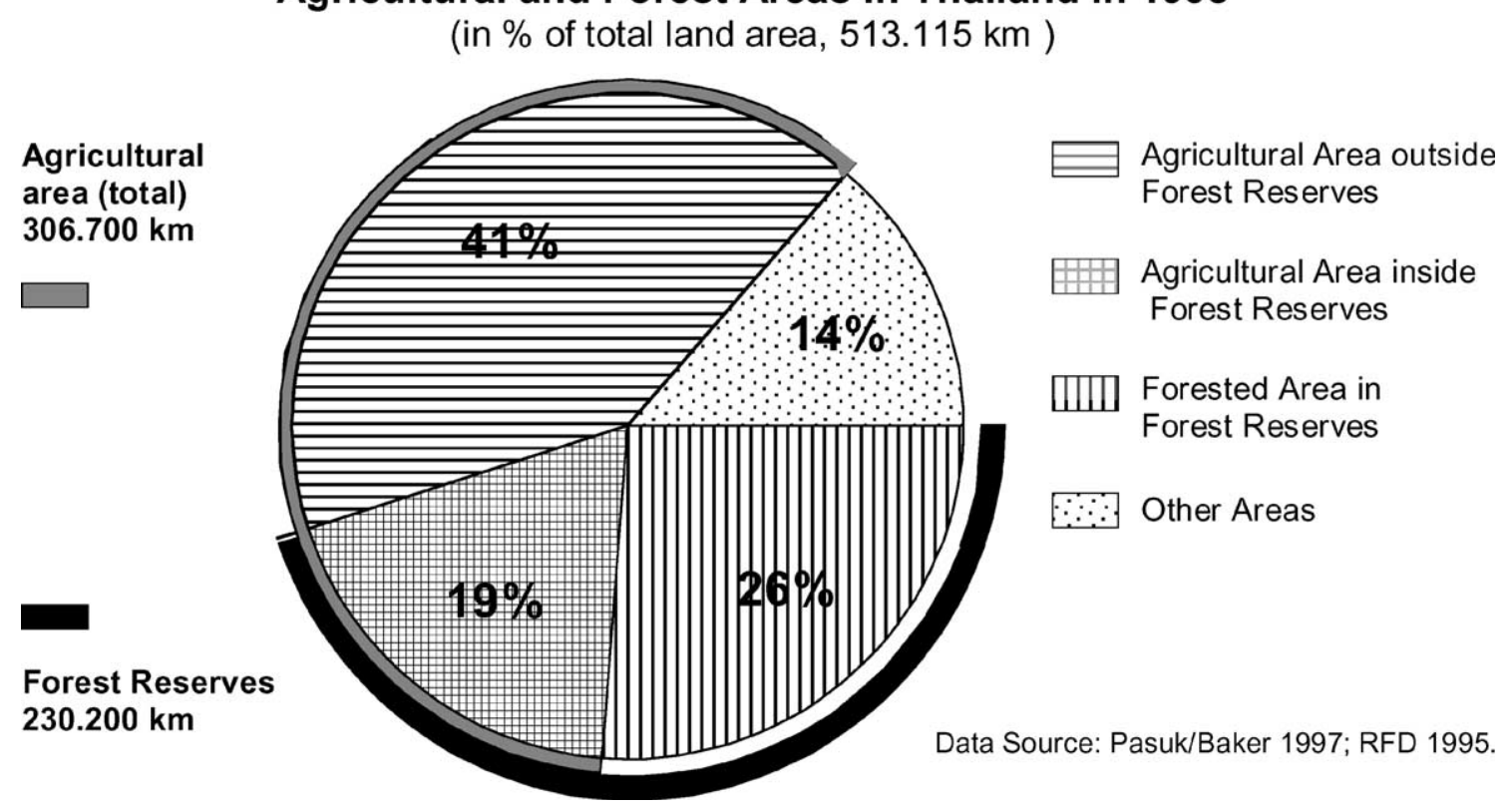

Fig. 3. Agricultural and forest areas in Thailand in 1993.

forestry in the British colonies, the new strategy was based on a zoning approach that had its origins in the United States, and that had come to be a prominent concept in international conservationism. In Thailand it was adopted mainly via education of Thai foresters in the United States (Kamon and Thomas, 1990, p. 171). The idea of zoning the country's land area according to suitability and function based on scientific criteria had already formed the basis for Thailand's National Forest Policy of 1985. It became central to the concept of the 'protected area system' (PAS) that was set out in the Thai Forestry Sector Master Plan (TFSMP) of 1993, and which today is conceived of as the main instrument of nature conservation in Thailand.

\section{From commercial to conservation forestry}

In the middle of the 1980s, the RFD was still concentrating on commercial forestry, aiming at a quarter 
of the total land area to be designated as commercial forest areas, besides $15 \%$ for conservation areas. Due to rising critique regarding deforestation and the RFD's commercial orientation, as well as due to resistance against its resettlement policy in the forest reserves, the agency was forced to considerably shift its focus to conservation forestry, not least reflected in the TFSMP.

The TFSMP has its origins in the context of the international Tropical Forestry Action Programme (TFAP) that was established in cooperation of FAO, WRI (World Resources Institute), UNDP, and World Bank in the beginning 1980s, when international concern about deforestation in tropical countries was growing. ${ }^{6}$ The TFSMP was supposed to be the basis for the implementation of the National Forest Policy. It was designed by the Finish consultancy company Jaakko Pöyry on behalf of the Thai Government and with financial support from the Finish Government, integrating Thai NGOs into the drafting of the plan largely failed (see Carrere and Lohmann, 1996, pp. 242-245; Orawan, 1992, pp. 61-66).

According to the plan, $28 \%$ of the total land area is to be reserved for the PAS. Outside of this area, another $15 \%$ of the land area is to be dedicated to commercial forests, aiming at a total forest cover of almost $44 \%$ of the land area. The PAS is to include all the still existing 'natural' forests, as well as all protected areas and watershed areas (RFD, 1993). Generally, the TFSMP leaves no doubt about the absolute priority of conservation objectives in the PAS and the desirability to remove people living in these areas. But, with its background in international conservation discourse, and pointing to the foreseeable problems of forced resettlements, the plan is rather moderate in its position towards resettlement, making it conditional on the consent of the concerned population, in contrast to objectives and practice of the RFD. This may be one of the reasons why the TFSMP was never passed by the Cabinet. Though, its fundamental objectives of designating $27.5 \%$ of the land area to the PAS and another $16 \%$ as commercial forest area was already passed in 1992 (Bhadharajaya, 1996, p. 11).

The fact that, already in the middle of the 1980 s, about one third of the forest reserve area was used as 'agricultural area', while apart from the forest reserves

\footnotetext{
${ }^{6}$ Lohmann points to the 'cultural context' of the program and 'particular' interests that may be behind 'global politics' when he suggests to look for its origins in a Washington bar: “... the Tropical Forests Action Programme (TFAP), a gigantic scheme which had originated in an early 1980s conversation in a Washington bar between the World Bank forester John Spears and a colleague, who were brainstorming ways of getting more international development funding for professional forestry consultants in the new atmosphere of concern in world capitals for tropical forests." (Carrere and Lohmann, 1996, p. 242).
}

there was hardly any unclaimed land suitable for agricultural purposes, reveals the naivety or calculation of propagating the TFSMP as a solution to deforestation and 'encroachment' on forest reserves. Therefore it is not surprising that the conflicts between local communities and the RFD mounted up throughout the late 1980s and early 1990s, focusing predominantly on forests and reafforestation projects.

In the context of these conflicts a strong civil society movement emerged during the 1980s which, specifically in its more 'people oriented' parts, conceived the RFD as one of its main opponents. In the 1990s, the debate on community forests and the issue of people living in forest reserves became an important field of politics and societal controversy on social justice, resource control, land rights, democratization, and decentralization. The outcome of this controversy, that to a large extent developed in the context of the drafting of a Community Forest Bill, is still open (Brenner et al., 1999; Buergin and Kessler, 1999, 2000; Pearmsak, 2000; RECOFTC, 2002). On the one side of this controversy there are the Forest Department, conservation oriented academics, and so-called 'dark green' NGOs who concentrate on conservation issues. They believe people and forests cannot co-exist' and argue that the protection of forests is only possible if human settlements in forest areas are removed. In opposition to these groups with a focus on nature conservation there are various groups of the peasant movement, socially concerned academics, and so-called 'light green' or 'people oriented' NGOs who concentrate on the interests and problems of rural communities. They presuppose a vital interest of local communities in the protection of their local forests as a source of livelihood, as well as for its ecological and cultural functions (Yos, 1992; TDN, 1994; Anan, 1998; Watershed, 1998; Sayamol and Brodt, 2000).

Already in 1989, due to broad public pressure, the RFD had been forced to consent to a nation wide 'logging ban'. ${ }^{7}$ Now, wood predominantly had to be imported from neighbouring countries, specifically Malaysia, Burma, Cambodia, Laos, and Vietnam (RFD, 1995). Besides this blow to the commercial orientation of the RFD, in the beginning of the 1990s it became obvious that resettlement of then about 12 million people living in the forest reserves was no more feasible. This was clearly indicated by the failure of two big resettlement projects of the Military.

Similar to the RFD, the Military also had to face increasing problems of legitimacy in the middle of the

\footnotetext{
${ }^{7}$ Due to heavy floods and land slides in the south of the country in November 1988 , attributed primarily to deforestation and the establishment of rubber plantations, more than 250 people had died, forcing the Government to declare a logging ban. Regarding the events leading to the ban see PER (1992, 14f). For a critical analysis of the arguments on the causes of the flooding see McKinnon (1997).
} 
1980s. After the defeat of the communist insurgency in Thailand in the early 1980s, and with the decreasing influence of communism in neighbouring countries, the main justification for political dominance of the Military became shaky. At the same time, the new economic elites who emerged in the process of modernization and economic development increasingly demanded political influence, challenging power positions of the Military. In this situation the Military turned to rural development and 'forest conservation' as new tasks to justify power and political influence (Perapong, 1992). The Military's need for reputation grew even more after its last coup attempt was terminated by broad public resistance in May 1992.

Engagement in rural development had already been part of anti-communist strategies of the Military since the 1960s. Reafforestation with commercial eucalyptus plantations and 'forest conservation' were a rather new field of interest, even though, high military officials frequently had strong interests in the logging business, and deforestation had been deployed in counterinsurgency. Two projects of national importance mark the engagement of the Military in forest policies: the Isan Kiew or 'Green Northeast' project in the middle of the 1980s, and the Khor Jor Kor project of the early 1990s. In accordance with the forest policies of the RFD, both reafforestation projects relied on the forced resettlement of people living in forest reserves-projected 1, 2 and 6 million people respectively. Both projects failed, mainly due to heavy local resistance supported by a growing peasant movement, student groups, and NGOs (see Perapong, 1992, pp. 82-185, 208-217; PER, 1992, pp. 68-77; Pasuk and Baker, 1997, 83f).

In this situation the PAS became of main concern for the RFD as a way to secure authority over large areas as well as positions of power within the state bureaucracy and society. Protected areas were extended considerably from about $10 \%$ in 1985 to more than $17 \%$ of the land area in 1999, with the objective to enlarge up to $28 \%$ (RFD, 1993). The appeal of the PAS to the RFD, to a high degree, is due to its deep rootedness in prominent international and national conservationism. But, there is yet another aspect to the PAS improving the chances of the RFD to succeed in establishing a conservation area free of human interference encompassing more than a quarter of the country's land area. The people living in areas designated for the PAS predominantly are people of ethnic minority groups with a most precarious status in Thai society.

\section{Shifting views on forests and hill tribes}

The RFD's estimates in 1998 accounted for about 600,000 people living in areas designated for the PAS. Contrary to the majority of the estimated 12 million people living in forest reserves altogether who are predominantly ethnic Tai, most of the people within the PAS are members of one of the various ethnic minority groups categorized as chao khao or 'hill tribes'. The term chao khao came into use in the 1950s as a generic name for various non-Tai groups living predominantly in the uplands of northern and western Thailand. Very soon the term was identified with a negative stereotype of forest destroying, opium cultivating, dangerous foreign troublemakers. Originally this image was mainly derived from the Hmong ethnic minority group, as their shifting cultivation systems frequently included opium cultivation, and some of them were involved in the communist insurgencies of the 1960s. It was soon branded on all the different groups categorized as 'hill tribes'.

Historically and ideologically the term chao khao ('hill people') is related to the term chao pha ('forest people') which was frequently used to denote these nonTai minority groups before the term chao khao came into use. Among the various ethnic Tai groups of Southeast Asia, pha - referring to 'forest', 'wild', 'savage'-generally is conceived as opposite to muangreferring to 'civility' or the 'human domain'. Frequently, the pole of 'civility' was identified with dominating ethnic Tai groups, while the 'forest/wilderness' pole was related to marginal ethnic minority groups at the edge of the Tai polities (Stott, 1991; Turton, 2000; Thongchai, 2000b).

Towards the end of the 19th century, the elites of the emerging Siamese nation state increasingly merged their conceptions of muang with the Western concepts of 'modernity'. Urban Thai culture, identified with the chao krung or 'city people' and shaped according to Western concepts of state, science, and economics, became the model for 'modernization' and 'national development'. Rural Thai culture, personified in the chao bannok or 'villagers'-generally paddy growing Buddhist peasants living in the valleys, not necessarily ethnic Tai-was perceived as backward in time and development, but within the space of 'civility'. Therefore, they had the potential for modernization, even more, were perceived as a resource for development. Outside of this space of 'civility', even refusing 'civilization', were the 'wild' nonTai people of the forests, the chao pha (Thongchai, 2000a).

During the 19th century, these 'forest people' had been of considerable importance for the ruling elites of the various regional centres, facilitating access to the resources of the forests.

Except for rice, the Thais had produced few of their export goods at that time and had relied on upland and forest peoples like the Karens to supply them with the bulk of their export wares. However, British domination of Thai export economy after the Bowring Treaty of 1855, King Mongkut's adoption 
of silver suai, and, in 1869, the completion of the Suez Canal, which made the marketing of bulk goods to Europe feasible, combined to undercut the Karen's importance to the Thai economy. Thailand's economy was transformed from an Asia-oriented barter economy specializing in luxury exports such as rhinoceros horns and sappan wood to a Europe-oriented money economy specializing in bulk exports such as rice and teak. (Renard, 1980, 24f).

In the process of the economic globalization of the region the 'forest people' lost their importance and, at the beginning of the 20th century, the ruling elites perceived them as unsuitable for modernization and to be left on their own. It was not before the middle of the 20 th century, when the state in the name of modernization, national security, and 'international' anti-communism expanded into the peripheral forest and mountain areas, that the chao pha re-emerged in national politics as the troublesome chao khao or "hill tribes' (Thongchai, 2000a; Renard, 2000). The forests, which had been their appropriate even though discrediting 'environment' at the turn of the last century, were now redefined as a resource for national development in the process of modernization.

The framing of the new social category chao khao was part of a process of nation building in which, during the first half of the 20th century, national identity and definition of 'Thai-ness' was linked to certain cultural traits, in particular Thai-Buddhism, language, and Monarchy. Furthermore, at the latest since the 1950s, Thai-ness is frequently related to a specific, culturally defined pattern of livelihood and residence. Recalling the frames established at the turn of the century, Thai-ness and suitability for inclusion into the Thai nation is made dependent on a 'civilized' way of living, specifically: living in the valleys - not in the mountains or forests!, and growing paddy - no hill rice and swiddening! Referring to modern environmentalism and conservationism, in this frame, the Thai valley population and the nation are dependent on the undisturbed (unpopulated!) mountain forests that secure the national water supply as well as the ecological stability of the country. ${ }^{8}$ To differentiate swidden cultivation of 'hill tribes' from swidden practices of ethnic Tai the term rai lu'an loy came into official use during the 1950s. While the term $r a i$, generally used to denote swidden cultivation, is rather neutral and ethnically unspecific, the specification lu'an loy, referring to 'nomadic' movements, emphasizes negative connotations of 'shifting', 'ungovernable', 'un-

\footnotetext{
${ }^{8}$ Regarding scientific critique of the ecological assumptions of this frame of thought see for example McKinnon (1989), Chantaboon (1989), Lohmann (1995), Enters (1995), and Forsyth (1996, 1999).
}

stable', thereby signifying "the 'disloyal' characteristic of the "hill tribe' swiddeners to the Thai nation." (Pinkaew, 1999, p. 41)

In the 1950 s, the category of the chao khao was created to deal politically with the population living in the peripheral forest areas of the country, which at that time became of national and international interest. The people of these areas had been territorially included into the nation state, but were culturally excluded as "others within" (Thongchai, 2000a). In the shaping of this social category concepts of national identity, modernization, and conservationism were merged, defining the chao khao as non-Thai, underdeveloped, and environmentally destructive. This conception, to a high degree, determined national politics towards the people categorized as 'hill tribes' as well as their public perception. Until today it is a widespread and influential image in Thailand (Krisadawan, 1999), revived and exploited in the community forest debate and resource conflicts of the 1990s (Buergin and Kessler, 1999, 2000). In this perspective, the 'hill tribes' already due to their place of residence and their way of livelihood exclude themselves from the Thai nation, even worse, they are threatening the welfare of the country by destroying its forests.

\section{Hill tribe policies, resource conflicts and ethnicism}

In contrast to the stereotype, the 'hill tribes' are a very heterogenous group of ethnic minorities. Most of the people categorized as 'hill tribes' were never involved in the opium business or communist insurgency. The groups living at lower altitudes predominantly cultivate rice in established rotational swidden systems, in combination with paddy fields where possible. Groups living at higher altitudes 'traditionally' rather practised forms of shifting cultivation with long cultivation and very long fallow periods, frequently including opium cultivation. In the late 1990s the 'hill tribes' comprised about 840,000 people or $1.3 \%$ of the total population, and by now are far outnumbered by ethnic Tai even in the uplands of Northern Thailand. ${ }^{9}$

From the 1950s until today, policies towards these ethnic minorities have been concerned with the three problem areas attributed to 'the hill tribes': opium cultivation, national security - read anti-communism, and deforestation - read shifting cultivation (Buergin, 2000). During the 1960s and 1970s, the fight against opium cultivation and communist insurgency dominated hill

\footnotetext{
${ }^{9}$ For overviews on the various groups see McKinnon and Vienne (1989) and McKinnon and Wanat (1983); regarding different land use systems e.g. Kunstadter et al. (1978) and Schmidt-Vogt (1997, 2000); with a focus on changes in the uplands (Uhlig, 1980; Kunstadter and Kunstadter, 1992; McCaskill and Kampe, 1997).
} 
tribe policies. By the mid-1980s, both issues had lost most of their urgency. Now, most of the remaining forest areas were to be found in the uplands of northern and western Thailand - the settlement areas of the 'hill tribes'. Furthermore, deforestation had become a matter of public interest and 'forest conservation' became the major concern of hill tribe policies. At the same time, the Military assumed a central role for hill tribe policies, now predominantly a resettlement policy (Chupinit, 1988).

International and national scientists related to the Tribal Research Institute at Chiang Mai University, including its Director in personal communication (Wanat Bhruksasri, March 1990), had urgently expressed their concerns about the resettlement policy towards the end of the 1980s:

Throughout the period 1986-1988 in the last years of the Prem administration, the growing impatience with highlanders became clearer everyday. The idea took hold that since highlanders were cutting the forest, destroying the national watershed, endangering lowland property, were not citizens, constituted a security problem, grew narcotics and engaged in illegal trading activities then the quickest way to solve the problem was to simply move them out of the hills. This barrage of charges, advanced by leading national authorities provided a raison d'être for strong intervention, which was underscored by an increasing willingness to use the military and other paramilitary forces to move people from places like national parks, other forested areas and border zones where the government did not want highlanders to be, to places which the authorities considered more suitable. (McKinnon and Vienne, 1989, pp. xxiii-xxiv).

In the view of the RFD the 'hill tribes' had meanwhile become the main 'problem group' regarding deforestation. Already in the National Forest Policy of 1985 'hill tribes' are mentioned as 'forest degradation problem' in prominent position (RFD, 2001). Even more outspoken was a former Director General of the RFD in a talk to a group of Ph.D. students in March 1996, referring to the resettlement policy and the protection of the watersheds against encroachment by "hill tribers" as most important task of the RFD (Phairot, 1996). The present Director General of the RFD rather succinctly expressed his position on the occasion of an international seminar on community forestry, in September 1998, when he declared: "Man cannot co-exist with the forest". To justify the position of the RFD not to tolerate community forests in protected areas he further explained: "Humans can't live in the forest because human beings aren't animals. Unlike us, animals can adapt themselves to the wild or any environment naturally" (Bangkok Post 9.24.1998).
On the local level, with the spreading of ethnic Thai farmers into the uplands as well as the extension of cash cropping by some of the 'hill tribe' groups, induced and supported by the international and national opium substitution programs, conflicts between ethnic Thai and 'hill tribe' groups increased during the 1980s, specifically over land, forest, and water resources (Waranoot, 1995; Watershed, 1997, 1998; Pinkaew, 2000). At the beginning of the 1990s, these resource conflicts, often termed environmental conflicts, emerged as a national issue in the context of the debate over the Community Forest Bill and the so-called Chom Thong Conflict. NGOs established in local conflicts to support the interests of 'modern' Thai farmers against 'hill tribe' groups in Chom Thong District, together with Bangkok based 'dark green' conservation NGOs, now tried to push through their objective to remove the 'hill tribes' from the watershed areas on a national level and found their 'natural' ally in the RFD with its new conservation strategy (Buergin and Kessler, 1999, 2000; Pinkaew, 2000).

Towards the end of the 1990s, the ethnicist traits of these resource conflicts increasingly came to the fore, aiming at the territorial, social, and political exclusion of the 'hill tribes' in the context of a more or less outspoken, culturally defined Thai nationalism, even among high government officials. This discourse refers to the image of the 'hill tribes' as destroyers of the nation's watershed forests as well as the cultural framing of Thainess as incompatible with residence in watershed forests and swiddening. For example, in August 2000 a leader of the 'conservation' NGOs in the Chom Thong Conflict claimed that "This land is ours. We were here before. Hill people are not our people (chao khao mai chai chao $\mathrm{rao}$ ). If they were Thai, they would live down here in the lowlands.", or when the Director General of the RFD, on a forum at Thammasat University concerned with the Chom Thong Conflict, lamented that the territory of Thailand, which once belonged to the king, "is gradually being given away", and the Deputy Agricultural Minister argued that the problem was that " 90 per cent of the hill peoples are not Thai." (The Nation 09.18.2000).

At the moment, only about 240,000 of the more than 840,000 'hill tribe' people do have the status of Thai nationals (BP 7.25.01). Therefore, most of them even cannot refer to the existing legal provisions regarding their settlement and land use rights. Most of them, at best, do have a so-called 'Blue ID Card' and thor ror 13 residence permits, entitling them to stay in Thailand legally for five years and restricting freedom of movement to the district of registration. Contrary to the integration policy announced by the Government, the bureaucracy responsible for the naturalization of ethnic minority people is rather restrictive regarding these groups. Moreover, discretionary powers of the officials in the process of granting citizenship, quite often seem to 
be used for personal profit. (Regarding the status of 'hill tribe' people and public debate on it see e.g. McKinnon, 1989; Deuleu and Naess, 1997; Nation 7.23.1999; BP 12.31.2000; BP 7.19.2001; BP 9.2.2001.)

The shifts in forest and hill tribe policies in the context of the resource and environmental conflicts increasingly led to resettlement of 'hill tribe' villages as well as restrictions on their land use systems. Since 1998, pressure on the ethnic minority groups in the uplands seems to be growing once more, resulting in arbitrary arrests, forced resettlement, terror, and violence (see e.g. Watershed, 1998, 1999, 2001; Pinkaew, 2000). In May 1998, the Director General of the RFD signed an agreement with the Supreme Commander of the Army, specifying the cooperation of RFD and Army to protect Thailand's remaining forests. In this agreement the Army is given far reaching authorities as well as financial support for operations in forest areas where illegal immigration' and illegal large scale logging prevail, while the RFD is responsible for forest areas encroached by small scale farmers. According to this division of responsibilities, the RFD mainly will have to deal with Tai farmers predominantly living in degraded forest reserves, while the Military is supposed to deal with the non-Tai ethnic minority groups, often living in protected and watershed areas (Nation 5.9.98; BP 7.2.98). The fruits of this agreement were to be observed in a 'pilot project' of this alliance in the Thung Yai Naresuan Wildlife Sanctuary, core area of the Western Forest Complex conceived as the most important forest area within the PAS, and a global heritage since 1991.

\section{Disputed sanctuaries and politics of exclusion}

The idea to protect forests and wildlife in western Thailand by establishing two Wildlife Sanctuaries grew in the mid-1960s among conservation oriented officials of the RFD. At the same time, Western biologists had drawn attention to the zoological importance of the region. By then, deforestation was already proceeding considerably in other parts of the country, even though, this was generally not perceived as a problem, but rather as supporting national development and security. Due to strong logging and mining interests in the area, it was not before 1972 (Huai Kha Khaeng) and 1974 (Thung Yai Naresuan) that the two sanctuaries could be established.

During the 1960s, not only timber and ore, but also the water of the western forests as hydroelectric power resource became of interest for commercial profit and national development. Several big dams were planned to produce electricity for the growing urban centres. Until the middle of the 1980s, three dams had been finished, financed mainly by the World Bank and Japanese funds. The Nam Choan Dam, the last of the projected dams, was supposed to flood a forest area of about $223 \mathrm{~km}^{2}$ within the Thung Yai Naresuan Wildlife Sanctuary. The public dispute about the Nam Choan Project lasted for more than six years, dominating national politics and public debate in early 1988 before it was shelved in April that year, with few prospects of being revived ever again.

The success of the movement against the dam was not only a remarkable victory for conservationism in Thailand, but also a milestone for the development of Thailand's civil society and the process of democratization (Buergin and Kessler, 1999, 2000). The success of the movement against the dam depended on a broad temporary alliance of actors with quite different interests who put aside internal conflicts in the name of nature conservation. Furthermore, the opponents were supported by prominent international conservation groups. ${ }^{10}$ Of crucial importance was the broad and predominantly positive response of the media towards the resistance movement which furthered the general perception of an overwhelming opposition towards the dam. Fears for a student revolt, like the one that toppled the military regime in 1973, quite probably also influenced the decisions of the politicians who finally shelved the project. (For accounts of the conflict see e.g. Hirsch, 1988; Rigg, 1991.)

The people of the Karen ethnic minority group living in the area to be flooded never had a voice of their own in the debate. Within the committee established to decide about the project their existence was irrelevant. Their interests partly were brought into the debate by NGOs and Journalists, but hardly appeared as an important argument, very much in contrast to the forests and wildlife that finally emerged as the crucial factors. Pointing to the high value for nature conservation and biodiversity, the opponents on the national and international level had raised the possibility of declaring the area a World Heritage Site. Most outspoken in this regard were Veeravat Thiraprasat, then chief of the Thung Yai Naresuan Wildlife Sanctuary, and Prince Bernhard of the Netherlands, founder and former president of the WWF. This prestigious option would have been lost with a huge dam and reservoir in the middle of the two wildlife sanctuaries most promising to fulfil the requirements for a global heritage. Just before the Nam Choan Controversy reached its peak, Thailand had ratified the World Heritage Convention in December 1987. During a visit to Thailand in February 1988,

\footnotetext{
${ }^{10}$ The International Union for Conservation of Nature (IUCN) publicly criticized the project (BP 02.23.88). Prince Bernhard of the Netherlands spoke against the dam during a state visit (Nation 2.4.88), as did Prince Charles and his father Prince Philipp, acting president of the WWF (Nation 4.18.88). The British conservation journal 'The Ecologist' dedicated its issue of March 1988 to the Nam Choan Controversy, and the movement in Thailand was supported by international scientists and activists.
} 
Prince Bernhard had raised his concerns about the dam project in the wildlife sanctuary, emphasizing particularly the interest of the WWF to have the area declared a World Heritage Site which would require to give up the dam project. After the project was already shelved, student groups, NGOs, and academics again pushed forward the idea, fearing the dam project could be revived - something which seemed to be less probable in a World Heritage Site.

On behalf of the RFD the proposal to UNESCO was written by two persons who had been outspoken opponents in the Nam Choan Controversy: Belinda Stewart-Cox, who did research as a biologist in Huai Kha Khaeng, and Seub Nakhasathien, chief of the Huai Kha Khaeng Wildlife Sanctuary. Seub committed suicide on September 1, 1991, out of despair about missing support within the RFD, ${ }^{11}$ before Thailand's first Natural World Heritage Site was declared in December 1991. The 'outstanding universal value' of the site, in first place, was justified with the extraordinary high biodiversity due to its unique location at the junction of four biogeographic zones, as well as with its size and "the undisturbed nature of its habitats" (Seub and Stewart-Cox, 1990, p. 49). Despite this "undisturbed nature', the Karen in Thung Yai in the proposal were defined as a threat to the sanctuary and their resettlement was announced for the near future.

Guarding a global heritage not only brought prestige to the nation and the RFD, but also prospects of economic assets as well as increasing political importance to the sanctuaries. Immediately after the declaration, international organizations in cooperation with national partners began to plan and project in and around the sanctuaries. The most prominent and most important in terms of 'economic weight' was a joint project of the World Bank and the Ministry of Agriculture, designed to improve biodiversity conservation and protected areas management in Thailand. The proposed project was concentrating on the World Heritage Site with a time frame of five years, beginning in 1994, approving extension. The total project cost was estimated at US\$ 96 million to be covered with a grant fund of US\$ 20 million from the global environment facility (GEF), a US\$ 40 million loan from the World Bank, as well as funds from bilateral aid donors and the Royal Thai Government. The pre-investment study for the project (MIDAS, 1993) was disapproved by NGOs in Thailand who criticized its narrow conservation perspective, its top-

\footnotetext{
${ }^{11}$ Belinda Stewart-Cox commented on his death with grave reproaches towards his superiors at the RFD: "Seub's death was suicide - an act of despair - but it might as well have been murder. When he needed the support of his superiors to do the job they had asked him to do-stop the hunting and logging that was rampant in Huai Kha Khaeng at that time, master-minded by police and military officials - it was withheld. A terrible betrayal." (Stewart-Cox, 1998).
}

down approach, as well as the high costs of the project. The negotiations between World Bank, state agencies, and NGOs focused on the controversial issue of resettlement. The study had cautiously argued against resettlement in the specific case of the Karen villages in Thung Yai Naresuan Wildlife Sanctuary, though, in a rather ambivalent way and under strict conservation reservations. The detrimental effects of the villages and risks for the sanctuary were assessed relative low, while their resettlement was supposed to cause high costs and considerable difficulties. Keeping the option for resettlement open, a whole chapter was dedicated to its implementation. The negotiations only gradually led to convergence, and the NGOs denied their cooperation for a project based on the pre-investment study (Malee, 1994; Ewers, 1994; PER, 1995; World Bank, 1995). ${ }^{12}$

In the debate about the World Bank/GEF project for the World Heritage Site the Karen people living in and at the edge of the protected area had been a crucial issue. The Karen villages in Huai Kha Khaeng had already been removed in the 1970s when the Sri Nakarin Dam flooded their settlement areas (Jørgensen and Ewers Andersen, 1982; Jørgensen, 1996). During the 1980s and early 1990s, villages of the Hmong ethnic minority group were removed from Huai Kha Khaeng and Thung Yai Naresuan Wildlife Sanctuaries (Eudey, 1986, 1989; MIDAS, 1993). The resettlement of the remaining Karen in Thung Yai was announced in the management plan for the sanctuary, drafted in the late 1980s, as well as in the proposal for the World Heritage Site. But, when the RFD tried to remove them in the early 1990s, it had to reverse the resettlement scheme due to strong public criticism. Nevertheless, the objective to drive the Karen out of the sanctuary remained strong within the agency. During the following years, the RFD concentrated on the land use system of the Karen, allegedly being detrimental to the forests of the sanctuary.

In the context of the ethnicist turn of conservation policies and the resource conflicts between Tai lowlanders and 'hill tribes' heating up since 1998, the RFD under its new Director General took the offensive again in Thung Yai. On April 13 in 1999, the Director General himself flew into the wildlife sanctuary, landing with his helicopter at the place where the Karen had just started to celebrate an important annual religious festival sup-

\footnotetext{
${ }^{12}$ The project was stopped after grant funds from the GEF were made conditional on the ratification of the convention on biological diversity (CBD) in July 1994. In the controversy about the project the representative of the Bank had tried to exert moderate pressure, indicating that the limited funds of the GEF may go to other countries if the ratification of the CBD was delayed. In January 2002, the Convention still is not ratified, predominantly due to reservations of the Public Health Ministry and the Council of State. After ratification the project most probably will be on the agenda again. (Regarding the debate on the CBD see e.g. Ewers, 1994; PER, 1995; Amara, 1999.)
} 
posed to last for three days. The Director General requested to stop the ceremonies. Soon after, soldiers burned down religious shrines of the Karen. From April 18 to May 12, soldiers and forest rangers went to the Karen villages, demanded to stop growing rice, demolished huts and personal belongings, and burnt down a rice barn. When these events became public, the Director General of the RFD downplayed his role in the incidents, at first denying any military actions at all. In contrast to the Director General, the commander of the military troops involved seemed rather proud of the achievements. He declared the operation a 'pilot project' of the new alliance between the Military and the RFD agreed upon in May 1998 (see above), exemplary for their joint efforts to prevent forest destruction. Throughout the following months efforts to convince the Karen people to resettle 'voluntarily' continued. Military officials prohibited agricultural activities and prevented villagers from using their fields. Allegedly, they even confiscated identity cards and house registration papers while they raided villages, arresting people unwarranted for days and removing families without Thai identity cards. Even though the Senate Human Rights Panel criticized the incidents, RFD and Military continued with their joint resettlement program in November 2000, announcing further relocations of families as well as the preparation of the resettlement area for all the villages (BP 12.1.00; BP 12.7.00; BP 12.11.00).

\section{Local frames and livelihood}

In the beginning of the 21 st century about 3000 people are living in the Thung Yai Naresuan Wildlife Sanctuary. They are almost exclusively ethnic Karen. About $90 \%$ of them were born in Thailand, predominantly within the sanctuary itself (Buergin, 2002b). According to their traditions, their ancestors came to the area fleeing political and religious suppression in Burma after the Burmese had conquered the Mon Kingdoms of Lower Burma in the 18th century. The first written historic references to their residence in Thung Yai may be found in Thai chronicles of the late 18th century. In the early 19th century, Karen of this western border area received formal settlement rights from the Governor of Kanchanaburi, and their leader was conferred the rank of Siamese nobility Khun Suwan. When the status of the border area was raised to that of a muang or principality, between 1827 and 1839, the Karen leader of the muang was awarded the title of Phra Si Suwannakhiri by King Rama III (Renard, 1980, 20f). At the latest since 1873, Phra Si Suwannakhiri resided in Sanepong which became the centre of the muang, and nowadays is one of the Karen villages lying within the Thung Yai Naresuan Wildlife Sanctuary. During the second half of the 19th century this muang was of considerable importance to the Siamese Kings, guarding part of their western border with British-Burma, and Karen living there were consulted for the delineation of the border between Thailand and Burma under King Rama V (Renard, 1980, pp. 21-24; Thongchai, 1994, 72f). It was only in the beginning of the 20th century, after the modern Thai nation state was established, that the Karen in Thung Yai lost their former status and their importance for the Thai state, re-appearing on the national political agenda as forest encroachers and illegal immigrants towards the end of the 20th century.

The Karen in Thung Yai conceive themselves as people living in and of the forest, as part of a complex 'local community' of plants, animals, humans, and spiritual beings (see also Jørgensen, 1989; Pinkaew, 1992). Within this community the Karen do not feel as 'superiors', but rather as highly dependent on the various other beings and forces. Living in this community requires adaptation as well as highly specific knowledge about the interdependences and 'rules' of this community. Fostering relations to the various spiritual caretakers of the community is an integral and important part of Karen life in the sanctuary. Their permission and support has to be sought continuously in order to live in and make use of the forest. From a 'modern' perspective, many of these rules and 'traditions' may be termed 'ecological knowledge'. In these rules and norms as well as in their daily practice of livelihood, passed on and transformed from generation to generation, a very rich and highly specific knowledge about their 'environment' is contained and kept alive. This 'ecological knowledge' as well as the 'real' and 'imagined' local history of the Karen in Thung Yai is crucial for their identity.

The world 'outside', specifically the 'Thai world', is perceived by the Karen as very different, often incomprehensible, and rather threatening. Their relations with this outside world have been changing frequently in history, but regarding their 'internal affairs' the Karen in Thung Yai were largely autonomous until the early 1960s, when economic and political interests furthered the extension of state authority into the peripheral areas. The intrusion of Thai institutions into the 'living space' of the Karen, at first, triggered and shaped changes of the social, political, and religious organization of the Karen communities, while the economic organization of most of the households remained rather unchanged until the late 1980s and early 1990s (Buergin, 2002a).

Until today, most of the households in Thung Yai practise subsistence farming. They predominantly grow rice in swidden fields and some paddy fields, producing most of the basic provisions for subsistence locally. Their rotational swidden system depends on short cultivation and long fallow periods. Within a territory 'controlled' by the village community, every year each household selects a swidden field according to household size and work capacity. The secondary vegetation 
of a fallow area, predominantly a kind of bamboo forest, is cut, and burnt after a period of drying. After being used to grow hill rice, generally for one year, the field once again is left fallow for several years, while numerous plants growing in the fallow are used continuously. The long fallow periods of 5-15 years (and more) together with specific cultivation techniques support the long-term productivity of the soils. In the late 1990s, the Karen still were able to produce enough rice to meet the subsistence needs of the communities in the sanctuary within their traditional land use areas. ${ }^{13}$ In swidden fields, gardens, and forests a great variety of other plants is grown and collected. Fishing is important for protein provision, besides, various smaller animals are hunted and collected. Bigger animals, for fear of punishment as well as for reputation in the public discourse on their settlements, are not hunted anymore by the Karen living in the sanctuary (see also Steinmetz and Mather, 1996), causing them some problems as wild boar frequently ravage the fields of the Karen. Furthermore, a considerable part of the Karen are vegetarian (see also WFT, 1996), and most of the households disapprove raising pigs and chicken due to religious reasons. Small supplementing cash incomes are obtained in most households by way of selling chillies, tobacco, and various other fruits grown within the traditional land use system. Wage labour is of rather little importance in most households. The mean annual income per person in 1996 was below US\$ 50. (For a comprehensive account of the economic and social organization see Buergin, 2002b.)

\section{Transcultural resistance to conservation policies and modernization}

Since the RFD had to delay its resettlement plans in the early 1990s it is trying to abolish the rotational swidden system of the Karen by prohibiting the use of fallow areas older than three years. In the longer term, these restrictions necessarily will lead to the breakdown of the traditional land use system, as the soils under constant use rapidly lose their productivity. In the villages where control through RFD and Military was most effective, people already reported decreasing yields in the second half of the 1990s. By now, in early 2002, the RFD has started to plant tree seedlings on this year's swidden fields in some villages (R. Steinmetz, pers. Communication, February 2002), forcing the Karen to choose between being charged as forest destroyers or facing severe subsistence problems. The only possibility

\footnotetext{
${ }^{13}$ Even assuming a mean fallow period of 10 years, the total agricultural area in the sanctuary, including fallow areas, presently accounts for about $1 \%$ of its total area.
}

for the Karen to adapt to the restrictions on their swidden system, apart from trying to avoid them, seems to be 'modernization'. They may either try to increase the productivity of the fields, using fertilizers and pesticides - which most of them cannot afford, or right away turn to cash cropping in, or wage labour outside the sanctuary. Intensification of agriculture and cash cropping is already propagated and supported by some of the government institutions and NGOs working in the sanctuary. But most of the Karen in Thung Yai reject these efforts, trying to carry on with their subsistence farming. Furthermore, intensification of land use, cash cropping, and increasing market orientation - that is 'modernization'-leads to the destruction of their reputation as 'forest people living in harmony with nature' on which they have to base their claims to remain in the sanctuary.

Presently this 'image' is their most important asset in the national debate that will decide about the future of the villages in the sanctuary. In contrast to the predominating stereotype of the forest destroying 'hill tribes', the Karen in Thailand, and specifically those living in Thung Yai, are increasingly referred to as 'people living in harmony with nature', and cited as an example that 'people and forests can co-exist'. This position within Thailand's public discourse on people and forests originated in the rising conflicts about villages in forest reserves and forest policies towards the end of the 1980s. In resistance to resettlement policies in forest reserves, eucalyptus plantations, illegal logging and corruption, an emerging peasant movement, concerned academics, and NGOs developed a community forest concept as an alternative perspective and a countermodel to the conservation concept and commercial reafforestation approach of the RFD and big agribusiness companies (see above).

The Karen in Thung Yai find their allies among these groups. But for them it is a rather ambivalent 'alliance'. In their encounters with state agencies they frequently feel right and powerless. Open resistance to continuous repression and acts of violence by RFD and military officials is difficult for the Karen, not least due to specific cultural frames of behaviour and historically grounded interethnic relations between Karen and Tai. They have the impression that their rights and concerns are not relevant in the national and international discourses about their home place. Among them a strong feeling prevails that they cannot communicate their own view, that they have to use words, arguments, and ideas that are not really their own while trying to justify their claims, even towards their Thai allies among NGOs and activists. The Karen conceive these 'communication problems' not predominantly as language problems, even though many of the elder Karen have only limited competence in Thai language, but attribute them to different cultural contexts. 
Almost all of the Karen in Thung Yai believe that resettlement is neither justified nor desirable, but they do take different positions towards the external influences and the resettlement threat. There is a rather small group, including most of the Phu Yai Ban (the village head in the context of the state administrative system), which is open for 'moderate modernization' without having to give up Karen identity. The vast majority is rather more reluctant to changes, preferring to "live like our grandparents did" as a common saying goes. Among them there are marked differences in their reaction to the external influences. A rather big group, who may be labelled 'extroverted traditionalists', including many influential elders as well as young people, is trying to shape the changes and resist to the threats. They do so by trying to strengthen and revitalize Karen culture and identity as well as seeking support and advocacy outside of Thung Yai. Another group of more 'introverted traditionalists' focuses on strengthening 'traditional' Karen culture too, but invokes to a higher degree millenarian and more 'exclusive' frames of Karen culture, rather avoiding transcultural exchange and support.

Despite these differences of position and strategy, all these groups wish to remain in their villages as well as to protect their culture and living place. Furthermore, they all refer to the same specific cultural frame of values and objectives regarding a 'decent' life appropriate for a Karen living in Thung Yai. Sharpened, but not created in the clashes with external actors and influences, this conception of specific Karen values and objectives focuses on the concepts of 'modesty' in opposition to 'greed', 'harmony' in contrast to conflict, as well as 'spiritual development' versus 'material development'. The counterpart to these conceptions is quite obvious and explicitly named by the Karen as such. It is primarily the 'modern' Thai society which is increasingly 'intruding' into their traditional living places and spaces, threatening their 'cultural' and physical existence.

\section{Discursive hegemony and local representation in the process of global differentiation}

Looking back to what happened in and around Thung Yai from a 'global' perspective and with a rather large time scale, several major reframings of the area, its 'resources', the people, and the relations between the different actors emerge.

The first reframing occurred in the second half of the 19th century when, due to foreign colonial interests in the natural resources of the region, national boundaries were demarcated, and the modern territorial nation state was established according to Western models. In this process the Karen in Thung Yai were spatially included into the 'geo-body' of the Siamese nation state (Thongchai, 1994) which, at the same time, was included into a territorially and economically defined 'international community' that merged social and physical space globally.

The second reframing took place in the context of the nation building of the Siamese/Thai state during the first half of the 20th century. Basing Thai national identity on cultural features like language, Buddhism, Monarchy, and a specific way of living can be perceived as a process of differentiation, complementing processes of homogenization in the context of Thailands integration into the international community of territorial nation states. The Karen, who had been included into the state spatially, now were culturally excluded from it and disappeared from the political agenda.

In the middle of the 20th century, the third reframing was related to international and national modernization ideology and anti-communism, leading to rising economic and political interests in the peripheral areas. These 'frontier-areas' now were included into the national economy and became the base for economic development, while the people living there were conceived of as 'backward troublemakers' in conflict with national interests who had to be monitored and modernized.

The fourth reframing, since the 1980 s, predominantly took place in concepts of international and national conservationism. While in the context of the modernization ideology the peripheral areas were to be exploited as natural resources for human development, in the context of conservationism the remaining 'wilderness' has to be protected from humans, but as 'wilderness' is included into the 'global community' and managed on a national and global scale. In this frame, the Karen in Thung Yai are an alien element in a global 'natural' heritage and have to be carefully controlled if removal is not possible.

It is obvious that these reframings reflect shifting and conflicting interests - economic and ideological - of different social actors. Various concepts in social sciences have been deployed to account for these changes theoretically, most prominent among them concepts of the global spread of capitalism or modernization theories. I will not go into the pro's and con's of these theoretical approaches, but rather ask what the contextualizing perspective used in this paper may contribute to the present debate on the conflict.

The reframings depicted, first of all, are of a discursive nature, even though with increasingly serious practical implications for the people in Thung Yai. Since the middle of the 19th century, the discourses determining the status of the area and the people have been those of international and national elites, the framing being the result of negotiations of interests and shifting power relations. In these processes, the international and national discourses have adapted, became interrelated and mutually intelligible to a high degree. The Karen in Thung Yai have never had a chance to 
participate in these discourses. The local discourse of the Karen is largely irrelevant to the national and international discourses, and mainly unintelligible - even 'untranslatable' as the Karen would say. This situation is problematic in at least three aspects which are treated here as the problems of representation, social scale, and cultural frames.

All discourses about Thung Yai-on the 'local', 'national', and 'global' level-refer to the area as being an important part of the 'living space' of the respective 'community', worth of and in need for protection. However, they highly differ in interests and objectives. Assuming there is something like a 'national' or 'global community' with a respective 'living space' and respective rights to this space, Thung Yai seems to be a case of conflict of interests that has to be mediated politically. The concerned national and international 'communities' have committed themselves to principles of democracy and human rights, in the case of Thailand's new constitution conceding far reaching rights of local communities to their local resources and cultural self-determination (Thailand, 1997). Even though I am not a member of the Thai 'national community', I would wish that members of this community concerned with democratization and human rights engage to provide direct representation of the Karen in institutions concerned with the sanctuary, giving them a vote of their own. Their efforts are crucial for the Karen in Thung Yai and may be important for democracy in Thailand too. As a member of the 'global community' I feel easier to express my opinions on a World Heritage Site. Having adopted Thung Yai as a 'global heritage', the 'global community' has to assume responsibility for its heritage. As far as I can see, neither possible threats to 'its' heritage nor commitments of the international community to democracy and human rights warrant the forced removal of the Karen from Thung Yai. Asked whether they would agree to resettle if offered 'higher living standards' outside of the sanctuary, more than $98 \%$ of the Karen expressed their wish to stay in their home places (Buergin, 2002b). The international institutions concerned with the World Heritage Site should consider this vote, speak out against the acts of terror towards the Karen, and support their existence in Thung Yai.

The differences of easiness and 'legitimacy' I feel to raise concerns in different social contexts, on the one hand point to the problem of affiliation to social communities - the determination of inclusions and exclusions, on the other hand they point to the problem of autonomy versus heteronomy of social communities in relation to other social units, a problem increasing with growing social complexity. Besides the problem to determine and institutionalize the various spaces of selfdetermination from the 'local' to the 'global', growing interdependence between different levels of social space inevitably raises the problem of social scale. Generaliz- ing frames of thought and perception that are designed on 'national' or 'international' levels of social organization to fit interests and ideologies of these broader contexts, to some extent necessarily have to distort perceptions when applied to specific local situations. They may be highly inadequate and even counterproductive on all levels concerned if not adapted to local situations. This seems to be possible only through the participation of those concerned on the local level, in a process of framing and implementing 'higher level' interests that has to be open for adaptation and revision from below. The necessity for open participatory processes, by now, is widely recognized, but in practice is rather exception than rule, specifically in the context of conservation and modernization policies.

This not least is due to the almost ubiquitous problem of different cultural frames. Dominating 'communities' or 'cultures' frequently have a tendency to impose their cultural frames on other communities. Even if a willingness to be 'careful' with such impositions is presupposed, there still remains the problem to become aware of 'self-evident' cultural frames. The economic, political, and cultural processes of globalization throughout the 20th century, to a considerable degree, may be seen as resulting from efforts to define culturally specific frames of thought as 'universal' or 'global' and to impose them on other social contexts. This has been successful to such a degree that it is difficult to identify basic conceptions of the dominating 'culture of modernity' as culture specific concepts. ${ }^{14}$

Concepts that are central to modern identity and modernization ideology, like economic development, consumerism, continuous growth, and social competition, already have been identified as being, at least partly, a kind of counter-model for the values and objectives of the Karen in Thung Yai. Modern conservationism is closely related to modernization. Together with modernization it has its cultural roots within the ideological dissociation of 'humankind' and 'nature', and the assumption of man's supremacy over 'nature', a framing quite in contrast to the much more 'communal' and 'subordinate' conception of the Karen. Conservationism in the context of modernization is a means to subordinate 'nature' by defining it as a resource for human development, inserting it into the domain of human control. At the same time, it is an effort to regulate and compensate detrimental effects occurring in the process of modernization. In this context, 'modern' national and international discourses emphasize the re-

\footnotetext{
${ }^{14}$ Even within scientific discourses this 'culture of modernity' is predominantly framed in concepts claiming or presupposing universality for 'modernity', be it as a global historical epoch, an evolutionary stage of humankind, or a structural necessity in the development of social organization.
} 
sources of the sanctuary like forests, wildlife, or biodiversity as a legacy of 'humankind' and/or the 'nation', while the people in it are conceived of as a disruptive factor. To the Karen the modern concept of conservation is rather strange in its aspects of dissociation and domination. 'Regulating' their relations to their 'living space', and compensating for their interferences in this space are important aspects of the cultural frames and everyday life of the Karen too, even though implying quite different means and objectives compared to those of modern conservationism. The Karen refer to Thung Yai as their home, its 'resources' being basis of their livelihood, granted to them by the 'forest community' under the provision to take care of them.

Conceding the cultural background and relativity of concepts like 'modernization' and 'nature conservation', on the one side raises the question for the justification of imposing these cultural frames on others, on the other side renders them questionable and changeable. A new framing of the situation in Thung Yai should start from the appreciation of the conceptions and values of the Karen living there, and their self-perception of being an integral part of the 'sanctuary'. This perception, at least to some degree, is translatable into modern discourses, and, in this context, is supported by the studies done there so far (Pinkaew, 1992; Ambrosino, 1993; WFT, 1993, 1996; Chan-ek et al., 1995; Maxwell, 1995; Steinmetz, 1996; Steinmetz and Mather, 1996; Kulvadee, 1997; Buergin, 2002a,b). The Karen have considerably shaped the ecology of the sanctuary with their traditional land use system over a long time and increased its biodiversity. In their culture they keep a unique body of knowledge about their natural environment to which they maintain a specific and deep spiritual relationship. By way of recognizing their legitimate settlement and land use rights, supporting their sustainable land use system, integrating them into the management of the sanctuary, and securing their right to cultural selfdetermination, furthermore, the forests and the wildlife in Thung Yai will probably be protected most effective.

\section{References}

Amara, P., 1999. Forest policies and the convention on biological diversity in Thailand. In: Glück, P., Oesten, G., Schanz, H., Volz, K.-R. (Eds.), Formulation and Implementation of National Forest Programmes, vol. III. European Forest Institute, Joensuu, Finland.

Ambrosino, M., 1993. Comparison of the vegetative and soil characteristics of primary forest, secondary forest and forest fallow in Karen shifting agriculture. Unpublished report, Wildlife Fund Thailand, Bangkok.

Anan, G., 1998. The politics of conservation and the complexity of local control of forests in the Northern Thai highlands. Mountain Research and Development 18 (1), 71-82.

Bhadharajaya, R., 1996. Thai Forestry in Perspective. Royal Forest Department, Bangkok.
Braun, B., Castree, N. (Eds.), 1998. Remaking Reality. Nature at the Millennium. Routledge, London.

Brenner, V., Buergin, R., Kessler, C., Pye, O., Schwarzmeier, R., Sprung, R.-D., 1999. Thailand's community forest bill: U- turn or roundabout in forest policy? SEFUT Working Paper 3, Graduate College Socio-Economics of Forest Use in the Tropics and Subtropics, Freiburg.

Bryant, R.L., 1994. Fighting over forests: political reform, peasant resistance and the transformation of forest management in late colonial Burma. Journal of Commonwealth and Comparative Politics 32 (2), 244-260.

Bryant, R.L., 1997. The Political Ecology of Forestry in Burma1824 1994. Hurst, London.

Buergin, R., 2000. 'Hill tribes' and forests: minority policies and resource conflicts in Thailand. SEFUT Working Paper 7, Working Group Socio-Economics of Forest Use, Freiburg.

Buergin, R., 2002a. Local change and cultural identity of Pwo Karen communities in Thung Yai Naresuan Wildlife Sanctuary, Western Thailand. SEFUT Working Paper 11, Working Group SocioEconomics of Forest Use, Freiburg.

Buergin, R., 2002b. Lokaler Wandel und kulturelle Identität im Spannungsfeld nationaler Modernisierung und globaler Umweltdiskurse. Die Karen im Thung Yai Naresuan Wildlife Sanctuary, einem 'Weltnaturerbe' im Westen Thailands. Ph.D. Diss. forthcoming, Universität Freiburg, Institut für Ethnologie.

Buergin, R., Kessler, C., 1999. Das Janusgesicht der Zivilgesellschaft: Demokratisierung und Widerstand im thailändischen Umweltdiskurs. SEFUT Working Paper 6, Working Group SocioEconomics of Forest Use, Freiburg.

Buergin, R., Kessler, C., 2000. Intrusions and exclusions: democratization in Thailand in the context of environmental discourses and resource conflicts. GeoJournal 52 (1), 71-80.

Carrere, R., Lohmann, L., 1996. Pulping the South. Industrial Tree Plantations and The World Paper Economy. Zed Books, London.

Chan-ek, T., Kulvadee, B., Ambrosino, M., 1995. The traditional farming system of the Karen of Sanehpong village, Thung-Yai Naresuan Wildlife Sanctuary, Kanchanaburi Province, Thailand. In: Wood, H., McDaniel, M., Warner, K. (Eds.), Community Development and Conservation of Forest Biodiversity Through Community Forestry. RECOFTC, Bangkok.

Chantaboon, S., 1989. Highland agriculture: from better to worse. In: McKinnon, J., Vienne, B. (Eds.), Hill Tribes Today. Golden Lotus, Bangkok, pp. 107-142.

Chupinit, K., 1988. Hill tribe relocation policy in Thailand. Cultural Survival Quarterly 12 (4), 2-6.

Cronon, W. (Ed.), 1996. Uncommon Ground. Rethinking the Human Place in Nature. Norton \& Company, New York.

De'Ath, C., 1992. A history of timber exports from Thailand with emphasis on the 1870-1937 period. Natural History Bulletin of the Siam Society 40, 49-66.

Deuleu, C., Naess, M., 1997. Deuleu: a life history of an Akha woman. In: McCaskill, D., Kampe, K. (Eds.), Development or Domestication? Indigenous Peoples of Southeast Asia. Silkworm Books, Chiang Mai, pp. 183-204.

Enters, T., 1995. The economics of land degradation and resource conservation in northern Thailand: challenging the assumptions. In: Rigg, J. (Ed.), Counting the Costs Economic Growth and Environmental Change in Thailand. ISEAS, Singapore, pp. 90-110.

Eudey, A.A., 1986. Hill tribe peoples and primate conservation in Thailand. A preliminary assessment of the problem of reconciling shifting cultivation with conservation objectives. In: Else, J.G., Lee, P.C. (Eds.), Primate Ecology and Conservation. University Press, Cambridge, pp. 237-248.

Eudey, A.A., 1989. 14 April 1986: Eviction orders to the Hmong of Huai Yew Yee village, Huai Kha Khaeng Wildlife Sanctuary, Thailand. In: McKinnon, J., Vienne, B. (Eds.), Hill Tribes Today. Golden Lotus, Bangkok, pp. 249-259. 
Ewers, K., 1994. Politics of biodiversity conservation in Thailand: global and local discourse. In: Proceedings of the IIAS and NIAS Workshop on 'Environmental Movement in Asia', Leiden, October 27-29, 1994.

FAO Staff, 1957. Shifting cultivation: an appeal by FAO to governments, research centers, associations and private persons who are in a position to help. Unasylva 11 (1), 9-11.

Feeny, D., 1982. The Political Economy of Productivity. Thai Agricultural Development, 1880-1975. University of British Columbia Press, Vancouver.

Feeny, D., 1988. Agricultural expansion and forest depletion in Thailand 1900-1975. In: Richards, J.F., Tucker, R.P. (Eds.), World Deforestation in the Twentieth Century. Duke University Press, Durham, pp. 112-143.

Forsyth, T.J., 1996. Science, myth and knowledge: testing Himalayan environmental degradation in Thailand. Geoforum 27 (3), 375-392.

Forsyth, T.J., 1999. Questioning the impacts of shifting cultivation. Watershed 5 (1), 23-29.

Goldman, M. (Ed.), 1998. Privatizing Nature. Political Struggles for the Global Commons. Pluto Press, London.

Hirsch, P.H., 1987. Deforestation and development in Thailand. Singapore Journal of Tropical Geography 8 (2), 129-138.

Hirsch, P.H., 1988. Dammed or damned? Hydropower versus people's power. Bulletin of Concerned Asian Scholars 20 (1), 2-10.

Hirsch, P.H., 1990. Forests, forest reserve, and forest land in Thailand. The Geographical Journal 156 (2), 166-174.

Howitt, R., Connell, J., Hirsch, P. (Eds.), 1996. Resources, Nations and Indigenous Peoples: Case Studies from Australasia, Melanesia and Southeast Asia. Oxford University Press, Melbourne.

Jørgensen, A.B., 1989. A natural view: Pwo Karen notions of plants, landscapes, people. Folk 31, 21-51.

Jørgensen, A.B., 1996. Elephants or people: the debate on the Huai Kha Khaeng and Thung Yai Naresuan World Heritage Site, Paper prepared for the 48th Annual Meeting of the Association for Asian Studies, Honolulu, Hawaii, April 11-14.

Jørgensen, A.B., Ewers Andersen, K., 1982. Final report on Pwo Karen research in Changwat Uthai Thani, Amphur Ban Rai. National Research Council, Bangkok, January-February 1980.

Kamon, P., Thomas, D.E., 1990. Evolving management systems in Thailand. In: Poffenberger, M. (Ed.), Keepers of the Forest. Kumarian Press, West Hartford, Connecticut, pp. 167-186.

Krisadawan, H., 1999. Competing discourses on hill tribes: media representation of ethnic minorities in Thailand. Paper prepared for the 7th International Conference on Thai Studies, Amsterdam, 4-8 July 1999. IIAS; University of Amsterdam, Amsterdam.

Kulvadee, B., 1997. Institutional arrangements in communal resource mangement: a case study of a Karen village in a protected area. MA thesis, Mahidol University, Faculty of Graduate Studies, Bangkok.

Kunstadter, P., Kunstadter, S.L., 1992. Population movements and environmental changes in the hills of northern Thailand. In: Wijeyewardene, G., Chapman, E.C. (Eds.), Patterns and Illusions: Thai History and Thought. Australian National University, Canberra, pp. 17-56.

Kunstadter, P., Chapman, E.C., Sanga, S. (Eds.), 1978. Farmers in the Forest. Economic Development and Marginal Agriculture in Northern Thailand. University Press of Hawaii, Honolulu.

Lang, C., Pye, O., 2001. Blinded by science: the invention of scientific forestry and its influence in the Mekong Region. Watershed 6 (2), 25-34.

Lipschutz, R.D., Conca, K. (Eds.), 1993. The State and Social Power in Global Environmental Politics. Columbia University Press, New York.

Lohmann, L., 1993. Land, power and forest colonization in Thailand. Global Ecology and Biogeography Letters 3 (4-6), 180-191.

Lohmann, L., 1995. Against the myths. In: Colchester, M., Lohmann, L. (Eds.), The Struggle for Land and the Fate of the Forests. Zed Books, London, pp. 16-34.
Malee, T., 1994. World Bank repeating the same mistakes in GEF? Thai Development Newsletter 24, 15-17.

Maxwell, J.F., 1995. Vegetation and vascular flora of the Ban Saneh Pawng area, Lai Wo Subdistrict, Sangklaburi District, Kanchanaburi Province, Thailand. Natural History Bulletin of the Siam Society $43,131-170$.

McCaskill, D., Kampe, K. (Eds.), 1997. Development of Domestication? Indigenous Peoples of Southeast Asia. Silkworm Book, Chiang Mai.

McKinnon, J.M., 1989. Structural assimilation and the consensus: clearing grounds on which to rearrange our thoughts. In: McKinnon, J., Vienne, B. (Eds.), Hill Tribes Today. Golden Lotus, Bangkok, pp. 303-359.

McKinnon, J.M., 1997. The forests of Thailand: strike up the ban? In: McCaskill, D., Kampe, K. (Eds.), Development or Domestication? Indigenous Peoples of Southeast Asia. Silkworm Books, Chiang Mai, pp. 117-131.

McKinnon, J.M., Vienne, B. (Eds.), 1989. Hill Tribes Today. Golden Lotus, Bangkok.

McKinnon, J.M., Wanat, B. (Eds.), 1983. Highlanders of Thailand. Oxford University Press, Kuala Lumpur.

McNeely, J.A., Miller, K.R. (Eds.), 1984. National Parks, Conservation, and Development: The Role of Protected Areas in Sustaining Society (Proceedings of the World Congress on National Parks, Bali, Indonesia, October 11-22, 1982). Smithsonian Institution Press, Washington, DC.

Merchant, C., 1983. The Death of Nature: Women, Ecology and the Scientific Revolution. Harper \& Row, San Francisco.

MIDAS, 1993. Conservation forest area protection, management, and development project. Pre-investment study. Final report. Bangkok, October 1993.

Nash, R., 1982. Wilderness and the American Mind. Yale University Press, New Haven.

Orawan, K., 1992. Commercial reforestation policy. In: PER, (Ed.), The Future of People and Forests in Thailand after the Logging Ban. Paap Pim Printing, Bangkok, pp. 56-78.

Pasuk, P., Baker, C., 1997. Thailand. Economy and Politics. Oxford University Press, Oxford.

Pearmsak, M., 2000. The evolution of the policy making process: will there ever be a community forestry bill? Asia-Pacific Community Forestry Newsletter 13 (2), 58-62.

Peluso, N.L., 1992. Rich Forests, Poor People. Resource Control and Resistance in Java. University of California Press, Berkeley.

PER (Project for Ecological Recovery), 1992. The Future of People and Forests in Thailand after the Logging Ban. Paap Pim Printing, Bangkok.

PER (Project for Ecological Recovery), 1995. Protecting Thailand's biological diversity. A discussion paper on Thailand's Conservation Area Protection, Management, and Development Project. PER, Bangkok.

Perapong, M., 1992. The changing role of the Thai military from orthodox function to national development. Ph.D. Dissertation, Fakultät für Soziologie, Bielefeld.

Phairot, S., 1996. Past-present-future of Thai forestry. (unpubl. ms.) Bangkok.

Pinkaew, L., 1992. Ecological knowledge of an agricultural community in the forest: a case study of Karen in Thung Yai Naresuan Wildlife Sanctuary. MA thesis in Thai, Thammasat University, Bangkok.

Pinkaew, L., 1999. Rai, rai lu'an loy, rai mun wian and the politics of 'shifting cultivation'. Watershed 5 (1), 39-46.

Pinkaew, L., 2000. The ambiguity of 'watershed': the politics of people and conservation in northern Thailand. Sojourn 15 (1), 52-75.

RECOFTC, 2002. RECOFTC E-letter 2002.6 (March 15, 2002). Regional Community Forestry Training Center for Asia and the Pacific (RECOFTC), Bangkok.

Renard, R.D., 1980. The role of the Karens in Thai society during the Early Bangkok Period, 1782-1873. Contributions to Asian Studies $15,16-28$. 
Renard, R.D., 1987. The delineation of the Kayah states frontiers with Thailand: 1809-1894. Journal of Southeast Asian Studies 18 (1), 81-92.

Renard, R.D., 2000. The differential integration of hill people into the Thai state. In: Turton, A. (Ed.), Civility and Savagery. Curzon Press, Richmond, pp. 63-83.

RFD (Royal Forest Department), 1985. Forestry Statistics of Thailand for 1984. RFD, Bangkok.

RFD (Royal Forest Department), 1993. Thai Forestry Sector Master Plan. In: Subsectoral Plan for People and Forest Environment, vol. 5. RFD, Bangkok.

RFD (Royal Forest Department), 1995. Forestry Statistics of Thailand 1995. RFD, Bangkok.

RFD (Royal Forest Department), 1999. Forestry Statistics of Thailand 1999. RFD, Bangkok (Internet).

RFD (Royal Forest Department), 2001. Thailand National Forestry Policy. RFD, Bangkok. Available from < http://www.forest.go.th/ rfd/policy/policy_e.thm>.

Rigg, J., 1991. Thailand's Nam Choan Dam project: a case study of the 'greening' of South-East Asia. Global Ecology and Biogeography Letters 1 (1), 42-54.

Sathi, C., 1993. Thailand. In: Forestry Policies of Selected Countries in Asia and the Pacific. In: FAO (Ed.), In: FAO Forestry Paper, vol. 115. FAO, Rome, pp. 151-161.

Sayamol, K., Brodt, S., 2000. Networks - giving the people a voice in forest conservation planning. Forests, Trees and People Newsletter $42,69-75$.

Schmidt-Vogt, D., 1997. Swidden farming and fallow vegetation in Northern Thailand. Franz Steiner Verlag, Stuttgart.

Schmidt-Vogt, D., 2000. Indigenous knowledge and the use of fallow forests in Northern Thailand. In: Lawrence, A. (Ed.), Forestry, Forest Users and Research: New Ways of Learning. ETFRN, Wageningen, pp. 167-176.

Seub, N., Stewart-Cox, B., 1990. Nomination of the Thung Yai-Huai Kha Khaeng Wildlife Sanctuary to be a UNESCO World Heritage Site. Royal Forest Department, Bangkok.

Sompop, M., 1989. Economic Development of Thailand 1850-1950. Response to the Challenge of the World Economy. Institute of Asian Studies, Chulalongkorn University, Bangkok.

Steinlin, H., Pretzsch, J., 1984. Der tropische Feuchtwald in der internationalen Forstpolitik. Holz-Zentralblatt 138.

Steinmetz, R., 1996. Landscape Ecology and Wildlife Habitats: An Indigenous Karen Perspective in Thung Yai Wildlife Sanctuary of Western Thailand. Wildlife Fund Thailand, Bangkok.

Steinmetz, R., Mather, R., 1996. Impact of Karen villages on the fauna of Thung Yai Naresuan Wildlife Sanctuary. A participatory research project. Natural History Bulletin of the Siam Society 44, 23-40.

Stevens, S. (Ed.), 1997. Conservation through Cultural Survival. Indigenous Peoples and Protected Areas. Island Press, Washington, DC.

Stewart-Cox, B., 1998. Forests too precious for Seub legacy to be lost. Nation, September 28.

Stott, P.A., 1991. Mu'ang and Pa: Elite views of nature in a changing Thailand. In: Chitakasem, M., Turton, A. (Eds.), Thai Construction of Knowledge. School of Oriental and African Studies, London, pp. 142-154.

TDN (Thai Development Newsletter), 1994. The coexistence of people and their forests. Thai Development Newsletter, 26.
Thailand National Assembly, 1997. Constitution of the Kingdom of Thailand. Government of Thailand, Bangkok.

Thongchai, W., 1994. Siam mapped. A history of the geo-body of a nation. University of Hawaii Press, Honolulu.

Thongchai, W., 2000a. The others within: travel and ethno-spatial differenentiation of Siamese subjects 1885-1910. In: Turton, A. (Ed.), Civility and Savagery. Curzon Press, Richmond, pp. 38-62.

Thongchai, W., 2000b. The quest for 'Siwilai': a geographical discourse of civilizational thinking in the late nineteenth and early twentiethcentury Siam. Journal of Asian Studies 59 (3), 528-549.

Turton, A. (Ed.), 2000. Civility and Savagery. Social Identity in Tai States. Curzon Press, Richmond.

Uhlig, H., 1980. Problems of land use and recent settlement in Thailand's highland-lowland transition zone. In: Ives, J.D., Sabhasri, S., Voraurai, P. (Eds.), Conservation and Development in Northern Thailand. The United Nations University, Tokyo, pp. $33-42$.

Vandergeest, P., 1996a. Mapping nature: territorialization of forest rights in Thailand. Society and Natural Resources 9 (2), 159-175.

Vandergeest, P., 1996b. Property rights in protected areas: obstacles to community involvement as a solution in Thailand. Environmental Conservation 23 (3), 259-268.

Waranoot, T., 1995. Highland-lowland conflict over natural resources: a case of Mae Soi, Chiang Mai, Thailand. Society and Natural Resources 8, 279-288.

Warren, D.M., Slikkerveer, L.J., Brokensha, D. (Eds.), 1995. The Cultural Dimension of Development. Indigenous Knowledge Systems. Intermediate Technology Publications, London.

Watershed, 1997. Ethnicity and resources. Watershed 3 (1).

Watershed, 1998. Conflict or resolution? People and forests in northern Thailand. Watershed 4 (1), 10-28.

Watershed, 1999. Army troops demolish Karen homes in Thung Yai forest. Watershed 5 (1), 6 .

Watershed, 2001. This is like dying while still alive. Watershed 6 (2), 43-47.

Wells, M., Brandon, K., 1992. People and Parks: Linking Protected Area Management with Local Communities. The World Bank, Washington, DC.

Western, D., Pearl, M.C. (Eds.), 1989. Conservation for the TwentyFirst Century. Oxford University Press, New York.

Western, D., Wright, R.M. (Eds.), 1994. Natural Connections: Perspectives in Community-Based Conservation. Island Press, Washington, DC.

WFT (Wildlife Fund Thailand), 1993. Population Statistics for Laiwo Sub-district, Sangklabury District, Kanjanaburi Province, Thailand (as of April 1993). WFT, Bangkok.

WFT (Wildlife Fund Thailand), 1996. The study of natural resource use of Karen in Thungyai Naresuan Wildlife Sanctuary (Draft). WFT, Bangkok.

Williams, N.M., Baines, G. (Eds.), 1993. Traditional Ecological Knowledge. Wisdom for Sustainable Development. Centre for Resource and Environmental Studies, Canberra.

World Bank, 1995. Thailand. Assessment of Buffer Community Development and Protection of Conservation Forests Huay Kha Khaeng and Thung Yai Naresuan WS. RAMBOLL, Copenhagen.

World Bank, 1998. Revised Workplan. Bank Forest Sector Strategy and Policy Review. The World Bank, Washington.

Yos, S., 1992. Community-based natural resource management in Thailand. Asian Review 6, 78-124. 